KOŚCIÓŁ I PRAWO 10(23) 2021, nr 1, s. 239-251

DOI: http://dx.doi.org/10.18290/kip21101-13

\author{
Marek Story
}

\title{
POLOWANIA DUCHOWNYCH W ŚWIETLE ŚREDNIOWIECZNYCH KSIĄG POKUTNYCH
}

\section{WPROWADZENIE}

Od zarania dziejów lasy, bory i knieje były dla człowieka źródłem dostarczania nie tylko pożywienia, ale także odzienia i rożnych ozdób. Dlatego niebezpodstawnie uważa się, że polowanie było - obok zbieractwa jednym z najstarszych zajęć człowieka i sięga ono jego początków [Zarzycki 2009, 73].

Z czasem pojawiły się także inne cele dla których człowiek udawał się na polowanie. Wiązało się to chociażby z chęcią utrzymania równowagi środowiskowej, poprzez utrzymanie odpowiedniej struktury wiekowej i płciowej czy też uśmiercania chorych zwierząt. Postawa ta miała stanowić przejaw wrażliwości nad losem zwierzęcia [Micińska-Bojarek 2014, 96-97]. Polowanie dla wielu osób stało się też sposobem rozrywki, zabawy, a obecnie ma ono niekiedy wydźwięk komercyjny, poprzez organizowanie wyjazdów na tereny łowieckie, w których uczestniczyć mogą osoby nieposiadające kwalifikacji myśliwych. Do takich sytuacji dochodzi chociażby w niektórych krajach afrykańskich [Smykowski 2017, 228-29]1․

Ks. DR MAREK StORY - Katedra Nauk o Państwie i Prawie, Wyższa Szkoła Prawa i Administracji Rzeszowskiej Szkoły Wyższej; adres do korespondencji: ul. Cegielniana 14, 35-310 Rzeszów, Polska; e-mail: mks80@wp.pl; https://orcid.org/0000-0003-3637-9684

${ }^{1} \mathrm{Na}$ Białorusi można polować na gatunki, które w Polsce są chronione, takie jak głuszce, cietrzewie, niedźwiedzie brunatne, żubry i rysie. Równie atrakcyjne są polowania w Kazachstanie, Tadżykistanie i innych dawnych republikach radzieckich. 
We współczesnych realiach wielokrotnie w różnych dyskusjach, chociażby po opublikowaniu przez papieża Franciszka w 2015 r. encykliki Laudato $s i^{2}$, pojawiają się pytania dotyczące słuszności praktyk łowieckich, ich społecznej roli, czy etycznej oceny tychże zachowań [Mitek-Dziemba 2018, 71-87]. Stawiane są też pytania, czy polowanie nie stanowi naruszenia praw zwierząt i jednocześnie, czy człowiek nie przekracza przysługujących mu uprawnień i nie nadużywa swojej wyjątkowej pozycji [Smykowski $2017,227]^{3}$.

Mimo tych pytań zagadnienie prawa łowieckiego nie było dotychczas przedmiotem szerszego zainteresowania polskiej nauki i - jak słusznie zauważa W. Daniłowicz - było przez lata traktowane po macoszemu [Daniłowicz 2018, 16]. Należy też podkreślić, że przez lata aktywność łowiecka była akceptowana społecznie, a polowania stanowiły nobilitujący element życia wyższych sfer i w wielu kręgach były często traktowane jako elitarna i prestiżowa aktywność sportowa ${ }^{4}$. Obecnie polowania utraciły pewną akceptację społeczną, nie są mile widziane i jeśli brały w nich udział osoby pełniące funkcje publiczne, wymaga to później usprawiedliwienia [Piątek 2020, 135-36].

\section{KOŚCIÓŁ A ŁOWIECTWO}

„Postawa Kościoła wobec łowiectwa była zawsze pozytywna, natomiast postawa wobec polujących duchownych była w historii różna" - takie zdanie wyraził w przedmowie do książki o dwóch ambonach, kościelnej i strzeleckiej, ks. Wojciech Frątczak, kapelan Polskiego Związku Łowieckiego [Nogaj 2013, 16]. Należy więc podkreślić, że w nauczaniu katolickim z jednej strony uważano łowiectwo w celu zdobycia pożywienia za moralnie

${ }^{2}$ Franciscus PP., Litterae encyclicae Laudato si' de communi domo colenda (24.05. 2015), AAS 107 (2015), s. 847-945; tekst polski: Ojciec Święty Franciszek, Encyklika Laudato Si'. W trosce o wspólny dom, Edycja Świętego Pawła, Częstochowa 2015, nr 52.

${ }^{3}$ Pojawiaja siẹ różne publikacie, które albo potẹpiaja myślistwo na podstawie wywodów społecznych, kulturowych, psychologicznych, pedagogicznych, prawnych i filozoficznych albo też takie, które na podstawie podobnych przesłanek podkreślają słuszność i walory myślistwa [Ganowicz-Bączyk 2016, 265-81; Micińska-Bojarek 2014; Dynak 2012; Probucka 2020; Łapiński 2002, 141-62; Morciniec 2005, 75-93; Nogaj 2013; Rancew-Sikora 2009; Singer 2004; Urbaniak 2017, 3-29].

${ }^{4}$ Analizując literaturę staropolską na próżno szukać tekstów krytycznych na temat myślistwa. 
usprawiedliwione, czy też próbowano sakralizować myślistwo ${ }^{5}$, poprzez przenikanie się kultury chrześcijańskiej i myśliwskiej [Piątek 2020, 150], lecz z drugiej strony polowanie na zwierzęta na przestrzeni wieków wzbudzało niekiedy spore kontrowersje. Jedną z przesłanek świadczących o tej nieufności ze strony Kościoła był zakaz zajmowania się tym przez duchownych, który jednak nie zawsze był respektowany ${ }^{6}$.

Dowodów świadczących o tym, aby duchowni nie angażowali się czynnie $\mathrm{w}$ łowiectwo zwłaszcza $\mathrm{w}$ polowania o charakterze rozrywkowym w prawodawstwie kościelnym okresu średniowiecza znajdziemy kilka. Należy do nich zaliczyć chociażby Tradycję Apostolską św. Hipolita (zm. 235), która wśród niedozwolonych zawodów dla chrześcijan, uznając je za nieczyste wymienia nie tylko gladiatorów, czy też ich nauczycieli, ale także „łowców zwierząt uczestniczących w polowaniach [Paprocki 1976, 156-57]. Według niego tym, którzy trudnią się myślistwem: „nie będzie wyjawione Święte Słowo, chyba że najpierw oczyszczą się i uwolnią od tych zajęć nieczystych" . Trudno więc sobie wyobrazić, aby św. Hipolit zezwalał osobom duchownym na aktywny udział w polowaniach.

Potwierdza to synod w Agde z 506 r., który zakazał polowań dla duchowieństwa. Zakazał on również duchownym, zarówno biskupom, prezbiterom oraz diakonom pod karą interdyktu utrzymywania psów myśliwskich i sokołów co potwierdzać może, że zakazy te odnosiły się do uprawiania polowań jako rozrywki. Podejmowano także próby rozszerzenia tego zakazu również na osoby świeckie. Jedną z nich podjęto na synodzie Kościoła wschodniego w Trullo w 692 r. Zabronił on urządzania polowań przez

\footnotetext{
5 „Symbioza pomiędzy myślistwem a Kościołem sprawiła, że obrzędy łowieckie miały swoje odpowiedniki wśród obrzędów kościelnych (np. chrzest jako introdukcja do wspólnoty wiernych i introdukcja myśliwego do wspólnoty łowieckiej), ceremoniał pogrzebowy myśliwego obok ceremoniału kościelnego zawiera także elementy ceremonii łowieckich. Z ceremoniału kościelnego wywodzi się ceremonia poświęcenia sztandaru, wznoszenie kapliczek myśliwskich i wiele innych analogicznych celebracji liturgicznych a nawet przykazania myśliwskie zawierające niepisany kodeks myśliwego zawierający zasady prawidłowego łowiectwa. W języku kościelnym i w języku łowieckim znajdujemy liczne odpowiedniki pojęciowe takie jak: ambona kościelna i ambona leśna, brać kościelna i brać łowiecka, chrzest kościelny i chrzest myśliwego" [Piątek 2020, 150].

${ }^{6}$ Udział w polowaniach rozpowszechnił się tak wśród polskich zakonników, że statuty synodalne z XIII w. musiały zakazać im brania udziału w polowaniach z udziałem psów i sokołów.

${ }^{7}$ Synody i kolekcje praw. T. III: Kanony Ojców Greckich (tekst grecki i polski). Atanazego i Hipolita (tekst arabski $i$ polski), układ i oprac. A. Baron, H. Pietras, Wydawnictwo WAM. Księża Jezuici, Kraków 2009, s. 183.
} 
osoby zarówno świeckie, jak i duchowne pod groźbą surowych kar. Jednakże uchwały tego synodu nie zyskały akceptacji papieży i nie weszły w życie [Daniłowicz 2020, 29-31].

Celem niniejszego artykułu jest udzielenie odpowiedzi, w jaki sposób udział duchownych różnego stopnia święceń - diakonów, prezbiterów i biskupów - postrzegały księgi pokutne.

\section{KSIĘGI POKUTNE}

Penitencjały zaczęły powstawać na przełomie V i VI w. i głównie są one związane z tradycją Kościoła iroszkockiego [Kumor 1973, 25] oraz brytyjskiego, ale spotyka się w nich również wpływy galijskie i italskie, które zapewne przenikały do tradycji monastycznej wczesnośredniowiecznych mnichów [Kieling 2017, 226] i są świadectwem kształtowania się praktyki pokutnej w Kościele. Księgi pokutne w VIII w. zostały przeniesione przez mnichów z Wysp na kontynent. Pod ich wpływem powstały Księgi w Galii i Północnej Italii, a następnie w Hiszpanii i Grecji.

W 2011 r. został wydany zbiór ksiąg penitencjalnych zatytułowany „Libri poenitentiales” (Księgi pokutne), autorstwa A. Barona i H. Pietrasa, który został podzielony na księgi irlandzkie i brytyjskie (21 pozycji), galijskie i italskie (13 pozycji), hiszpańskie (4 pozycje) i greckie (2 pozycje) w sumie ok. 500 stron ksiąg pokutnych, do których należy dodać kolejne 500 stron tekstu, będącego podstawą tłumaczenia, umieszczonego równolegle. Zatem jest to pokaźny tom z ponad 1000 stron, zawierających wykaz występków i sposoby ich zwalczania ${ }^{8}$.

Penitencjały miały przyjść z pomocą spowiednikom w zakresie nadawania pokut. Określały bowiem one w sposób bardzo precyzyjny kary i pokuty publiczne, jakie należało nałożyć za różnego rodzaju grzechy i występki. Były więc drobiazgowym zbiorem przepisów i zasad, jakimi winny się kierować osoby wyznaczające grzesznikowi pokutę, w praktyce duchowni przyjmujący spowiedź od wiernych. Jednocześnie księgi pokutne stanowiły pewnego rodzaju ogniwo łączące z jednej strony prawo, moralność i wiarę, a $\mathrm{z}$ drugiej - prawo cywilne $\mathrm{z}$ kościelnym, a poprzez to regulując i wpły-

${ }^{8}$ Synod i kolekcje praw. T. V: Księgi pokutne (tekst łaciński, grecki i polski), układ i oprac. A. Baron, H. Pietras, Wydawnictwo WAM. Księża Jezuici, Kraków 2011, s. 10551058 [dalej cyt.: Księgi pokutne]. 
wając na funkcjonowanie poszczególnych wspólnot, jak i postawy samych wiernych [Erdö 2008, 61].

Księgi pokutne, które obejmowały bardzo szeroki wachlarz grzechów czy też niewłaściwych postaw dotyczących m.in. sprawowania sakramentów, posługi duszpasterskiej i życia moralnego duchowieństwa, świętokradztwa, zabójstw, niewierności małżeńskiej, dewiacji seksualnych, odżywiania się, krzywoprzysięstwa, składania fałszywej przysięgi, kradzieży, pozbawiania innych dóbr, antykoncepcji, defraudacji, czy też magii nie stanowiły dotychczas szerszego zainteresowania dla opracowań naukowych [Góralski 2015, 59-78; Kieling 2012, 83-95; Tenże 2017, 225-40; Kwiatkowski 2012, 113-26; Pałęcki 2012, 127-55; Story 2020, 86-108; Szpetkowska 2000, 113-34; Witkowski 2019, 57-71; Zawadzki 2010, 181-95]. Fakt ten może zaskakiwać, bo penitencjały są jednym z pośrednich źródeł poznania prawa kanonicznego i oprócz sakramentarzy są zaliczane do zbiorów prawa specjalnego [Subera 1977, 62-65].

\section{SPOŻYWANIE MIĘSA I RYB A KSIĘGI POKUTNE}

Analizowane zagadnienie występuje w kilku penitencjałach i jest znane zarówno w księgach irlandzko-szkockich i brytyjskich, jak też tych późniejszych występujących na kontynencie. Przepisy dotyczące zakazu polowań przez duchownych zazwyczaj pojawiają się wśród zagadnień związanych ze zwierzętami. Znajdujemy bowiem szereg zakazów związanych ze spożywaniem zwierząt czy też przeciwnie takowych zezwoleń. Według chociażby Księgi pokutnej Pseudo-Kummeana nie wolno było spożywać zwierząt, które zostały rozszarpane przez wilki lub $\mathrm{psy}^{9}$, ani też jeleni lub kóz, jeśli zostały znalezione martwe. Zakazane było również przygotowywanie posiłków ze zwierząt, które udusiły się w sieci ${ }^{10}$, czy też były „skalane spółkowaniem" z człowiekiem ${ }^{11}$. Nie wolno było spożywać padliny lub mięsa

\footnotetext{
${ }^{9}$ Spożywać je można było tylko w przypadku, kiedy zostały dobite przez człowieka w wyniku wcześniejszego pogryzienia. Zwierzęta, które zostały znalezione jako rozszarpane, należało dać do spożycia psom lub świniom.

${ }^{10} \mathrm{~W}$ tym wypadku odwoływano się do Księgi Nowego Testamentu, a mianowicie Dziejów Apostolskich, która nakazywała powstrzymywać się od nierządu, krwi, zwierząt uduszonych i bałwochwalstwa (Dz 15, 20. 29).

${ }^{11}$ Takie zwierzęta należało zabić po roku od tego momentu, a mięso wyrzucić psom, można było jednocześnie korzystać z ich potomstwa i skór. W przypadku wątpliwości należało takie zwierzę zostawić przy życiu.
} 
nadjedzonego przez inne dzikie zwierzęta. Dodatkowo człowiek, który spożywał padlinę poza koniecznością wynikającą z głodu musiał pokutować przez 40 dni. Według tego penitencjału nie było natomiast zakazu spożywania ryb, zajęcy ${ }^{12}$ czy też koniny ${ }^{13}$.

Odnośnie do ryb wypowiada się w swoim penitencjale, żyjący w XIII w. arcybiskup Yorku św. Egbert, który zezwalał na spożywanie martwych ryb wyłowionych z rzeki, natomiast nie wolno było spożywać martwych ryb znalezionych w stawie. Za powyższe zachowanie przypisana była dla penitenta następująca pokuta: „niech pości cztery tygodnie w środy i piątki o chlebie i wodzie, w pozostałe dni niech się powstrzymuje od mięsa"14. Dopuszczalne było także spożywanie mięsa wieprzowego, pomimo, że świnia zjadła padlinę, to samo dotyczyło kur. Taką postawę tłumaczono tym, że w tym wypadku nie należy zmarnować mięsa z tych zwierząt przez ich wyrzucenie $^{15}$. Zdecydowanie zakazane było spożywanie krwi jakiegokolwiek zwierzęcia, gdyby ktoś to uczynił miał pokutować przez czterdzieści dni ${ }^{16}$.

\section{POLOWANIA DUCHOWNYCH A KSIĘGI POKUTNE}

W kwestii polowań księgi pokutne w sposób jednoznaczny potępiają takie praktyki wśród osób duchownych, natomiast nie ma tekstów, które świadczyłyby o tym, że osoby świeckie nie mogą lub nie powinny brać udziału w polowaniach. $\mathrm{Z}$ analizy penitencjałów wynika również, że pokuta za udział $\mathrm{w}$ polowaniach wydaje się być dość surowa, jeśli porównamy ją do innych pokut wymierzanych za poważne przewinienia.

Księgi irlandzkie i brytyjskie jako pierwsze podejmują aspekt polowania wśród osób, które przyjęły święcenia. W Księdze pokutnej Pseudo-Kummeana możemy zauważyć, że diakonowi za sam udział w polowaniu groziła dwuletnia pokuta, która jednak nie była dookreślona, na czym miała

\footnotetext{
12 Odnośnie do spożywania mięsa z zająca Teodor biskup Canterbury dodawał: „zająca wolno jeść i jest dobry na biegunkę, a jego żółć zmieszana z pieprzem na ból”. Zob. Discipulus Umbriensium (VII/VIII w.); tekst polski w: Księgi pokutne, s. 155.

${ }^{13}$ Księga pokutna Pseudo-Kummeana (VIII w.); tekst polski w: Księgi pokutne, s. 89-90.

${ }^{14}$ Penitencjat św. Egberta arcybiskupa Yorku w pięciu księgach (VIII w.); tekst polski w: Księgi pokutne, s. 235.

${ }^{15}$ Discipulus Umbriensium, s. 155.

${ }^{16}$ Księga pokutna Ps. Grzegorza III (IX w.); tekst polski w: Ksiegi pokutne, s. 358.
} 
ona polegać, natomiast prezbiterowi należało nałożyć trzyletnią pokutę ${ }^{17}$. Jeśli porównamy to z pokutą, którą duchowni mogli otrzymać za dokonanie zabójstwa, czyli diakon siedem lat, prezbiter dziesięć lat, a biskup dwanaście lat, to widzimy, że wymiar kary wydaje się rzeczywiście bardzo srogi $^{18}$. Wspomniany już arcybiskup Yorku św. Egbert doprecyzowuje, że pokuta za udział w polowaniu miała polegać na powstrzymaniu się od jedzenia mięsa przez diakona przez dwa lata, przez prezbitera trzy lata, a przez biskupa przez siedem lat ${ }^{19}$.

Najstarsza księga pokutna pochodząca z Francji z początku VIII w. (Księga pokutna $z$ Burundii) potwierdza rozwiązania irlandzko-brytyjskie, ale odnosi się jedynie do diakonów i prezbiterów ${ }^{20}$. Podobnie wydana kilka lat później (ok. 750 r.) Księga pokutna $z$ Paryża ${ }^{21}$, czy też penitencjał wydany ok. 830 r. przez biskupa Halitgariusa z Cambrai ${ }^{22}$ oraz Księga pokutna Ps. Grzegorza również z IX w. ${ }^{23}$

Powstałe później na terenie Włoch penitencjały zarówno w Florencji (ok. 775-800 r.) ${ }^{24}$, jak i na północy tego kraju także nic nie mówią o zakazie uczestnictwa w polowaniach dla biskupów, a jedynie odnoszą się do duchowieństwa niższego szczebla ${ }^{25}$. Natomiast według penitencjału pochodzą-

\footnotetext{
${ }^{17}$ Księga pokutna Pseudo-Kummeana, s. 90.

18 Tamże, s. 101.

${ }^{19}$ Penitencjat św. Egberta arcybiskupa Yorku w pięciu księgach, s. 235.

${ }^{20}$ Diakon miał pokutować dwa lata a prezbiter trzy lata. Ponadto tekst oryginalny „Si quis venationes quascumque exercuerit, clericus anno, diaconus II, sacerdos III paeniteat”, został przetłumaczony, że gdyby ktoś urządzał polowania, natomiast tłumaczeniem poprawnym jest praktykować. Zmienia to też sens znaczenia, bo czym innym jest organizować, a czym innym brać udział. Zob. Księga pokutna z Burgundii (700725); tekst polski w: Księgi pokutne, s. 264.

${ }^{21}$ Księga pokutna z Paryża (750); tekst polski w: Księgi pokutne, s. 273.

${ }^{22}$ Analizowana księga pokutna w sposób szczegółowy opisuje pokutę dla człowieka, który popełnił grzech zoofilii. Pokuta uzależniona była od wieku i stanu cywilnego grzesznika: „Gdyby ktoś zgrzeszył zwierzętami, a nie miał jeszcze 20 lat, po 15 latach pokuty, zasługuje na komunię modlitwy. Po 5 latach trwania w tej komunii może uczestniczyć w sakramencie ofiary. Niech rozważy się jego życie, od jak dawna czyni pokutę i na tej podstawie uzyska miłosierdzie. Jeśli zaś zupełnie przylgnął do tych grzechów, niech na pokutę poświęci długi czas. Jeśli ma ponad 20 lat i żonę, a upadł przywalony tym grzechem, niech czyni pokutę 25 lat i zostanie przyjęty do komunii modlitwy. Po 5 latach w tym stanie, może otrzymać sakrament ofiary. Jeśli są to ludzie żonaci, którzy przekroczyli 50 rok życia, niech pod koniec życia dostąpią łaski komunii”. Księga pokutna Halitgariusa, bp Cambrai (817-830); tekst polski w: Księgi pokutne, s. 323.

${ }^{23}$ Księga pokutna Ps. Grzegorza III, s. 359.

${ }^{24}$ Księga pokutna z Florencji (775-800); tekst polski w: Księgi pokutne, s. 281.

${ }^{25}$ Księga pokutna z Merseburga a (VIII w.); tekst polski w: Księgi pokutne, s. 292.
} 
cego z IX w. z obecnego Sankt Gallen w Szwajcarii zakaz uczestnictwa $\mathrm{w}$ polowaniach dotyczył jedynie diakonów ${ }^{26}$.

Zapiski odnośnie do polowań znajdują się również w księgach pokutnych powstałych na terytorium obecnej Hiszpanii, choćby powstały w XI w. penitencjał z Kordoby, który zakazywał udziału w polowaniach także biskupom ${ }^{27}$. Bardzo surowe pokuty znajdujemy w księdze pokutnej z klasztoru św. Dominika w Silos, znajdującej się na terenie diecezji Burgos, pochodzącej z tego samego okresu co księga pokutna z Kordoby. Otóż ten penitencjał postanawia, aby biskupi przez pięć lat czynili pokutę, jeśli brali udział w polowaniach $\mathrm{z}$ udziałem psów i sokołów, natomiast prezbiterzy mieli pokutować przez 3 lata za podobne uczynki ${ }^{28}$.

Należy też podkreślić, że zakaz uczestnictwa w polowaniach we wszystkich wspomnianych księgach pokutnych dotyczył także osób, które przygotowywały się do przyjęcia święceń diakonatu. Z dotychczasowej analizy wynika, że oprócz kandydatów do święceń, także diakonii mieli bezwzględny zakaz udziału w łowach. Zupełnie inaczej wyglądała sytuacja dotycząca aktywnego udziału w polowaniach prezbiterów i biskupów. Generalnie zakaz dotyczył też prezbiterów, ale w realiach irlandzko-brytyjskich i hiszpańskich w polowaniach nie mogli brać udziału także biskupi.

Wydaje się rzeczą słuszną zaakcentować, że udział osób świeckich w polowaniach nie był potępiany, nie wiązało się to z żadną dla nich pokutą, stąd też można wysuwać wniosek, że taki udział, czy też organizowanie polowań przez osoby, które nie przyjęły święceń żadnego szczebla był przez Kościól, jeśli nie pochwalany, to na pewno akceptowany.

Bez wątpienia na przestrzeni wieków zmieniał się stosunek prawodawstwa kościelnego wobec polujących księży, jak i samo podejście wiernych do udziału w polowaniach przez osoby duchowne. Także i obecnie ma ono swoich zwolenników, jak i zatwardziałych przeciwników.

\footnotetext{
${ }^{26}$ Księga pokutna ze Świętego Gallusa (IX w.); tekst polski w: Księgi pokutne, s. 344. Także i w tej księdze pokutnej mamy niepoprawne tłumaczenie. Zamiast urządzał polowania powinno być praktykował polowania.

${ }^{27}$ Księga pokutna $z$ Kordoby (XI w.); tekst polski w: Księgi pokutne, s. 439.

${ }^{28}$ Księga pokutna $z$ Silos (1060-1065), tekst polski w: Księgi pokutne, s. 471.
} 


\section{POLOWANIA W ŚWIETLE KODEKSU PRAWA KANONICZNEGO}

$\mathrm{Z}$ punku widzenia prawa kanonicznego sytuacja $\mathrm{w}$ XX w. uległa zdecydowanej zmianie i jeśli porównamy ją z księgami pokutnymi to widzimy, że jeśli na początku XX w. było wiele nici łączących te rozwiązania, to $\mathrm{z}$ biegiem czasu uległy one zupełnie rozluźnieniu.

Kodeks Prawa Kanonicznego z 1917 r. ${ }^{29}$, jak i Kodeks Prawa Kanonicznego z $1983 r r^{30}$ zawierają normę ogólną odnoszącą się do powstrzymywania się przez duchownych od zachowań, „które wprost nie przystoją ich stanowi" (kan. $285 \S 1 \mathrm{KPK} / 83$; kan. $139 \S 1 \mathrm{KPK} / 17)$ ). Ustawodawca w KPK/17 stanowił, że duchownym nie wolno było brać udziału w polowaniach zbiorowych $\mathrm{z}$ nagonką, natomiast pozwalał na uczestniczenie $\mathrm{w}$ polowaniach indywidualnych ${ }^{31}$.

Według K. Smykowskiego ten zakaz nie wynikał z racji dotyczących ochrony zwierząt lub troski o nie, ale swoje źródło czerpał z roztropności i rozwagi. Jego celem było zabezpieczenie przed przypadkowym spowodowaniem śmierci lub zranieniem naganiacza. Sprawcy śmierci lub doznaje poważnego uszczerbku na zdrowiu uznawani byli bowiem za niegodnych pełnienia funkcji kapłańskich [Smykowski 2017, 234].

Ustawodawca $\mathrm{w} \mathrm{KPK} / 83$ nie stanowi na temat polowań duchownych, jako sferze życia, w której powinni aktywnie brać udział lub też powstrzymywać się od niej w sposób radykalny [Gałkowski 2017, 111-22].

\section{PODSUMOWANIE}

Z punktu widzenia obowiązującego ustawodawstwa kościelnego nie ma przeszkód, aby duchowni brali udział w polowaniach, czy też otaczali

${ }^{29}$ Codex Iuris Canonici Pii X Pontificis Maximi iussu digestus Benedicti Papae XV auctoritate promulgatus (27.05.1917), AAS 9 (1917), pars II, s. 1-593 [dalej cyt.: KPK/17].

${ }^{30}$ Codex Iuris Canonici auctoritate Ioannis Pauli PP. II promulgatus (25.01.1983), AAS 75 (1983), pars II, s. 1-317; tekst polski: Kodeks Prawa Kanonicznego, przekład polski zatwierdzony przez Konferencję Episkopatu, Pallottinum, Poznań 1984 [dalej cyt.: KPK/83].

31 „Clerici ab iis omnibus quae statum suum dedecent, prorsus abstineant: indecoras artes ne exerceant; aleatoriis ludis, pecunia exposita, ne vacent; arma ne gestent, nisi quando iusta timendi causa subsit; venationi ne indulgeant, clamorosam autem nunquam exerceant; tabernas aliaque similia loca sine necessitate aut alia iusta causa ab Ordinario loci probata ne ingrediantur" (kan. 138 KPK/17). 
troską myśliwych, jak to miało miejsce w czasie, kiedy posługiwano się księgami pokutnymi. Penitencjały akceptowały, a na pewno nie zakazywały udziału w polowaniach osobom świeckim, w przeciwieństwie do osób duchownych. Zakaz ten obejmował przede wszystkim uczestnictwo w polowaniach, które miały charakter rozrywkowy.

Pozostaje natomiast otwarta kwestia oceny moralnej czynnego udziału duchownych $\mathrm{w}$ polowaniach, w których zgodnie $\mathrm{z}$ prawem kanonicznym mogą uczestniczyćs ${ }^{32}$.

Słuszne wydają się więc słowa, które W. Daniłowicz aplikuje całej braci myśliwskiej, a więc także do duchownych, którzy udają się na polowania: „myśliwi, dla których polowanie stanowi wyłącznie okazję do zabijania zwierzyny, postępują niezgodnie z zasadami wiary chrześcijańskiej. Tej oceny nie zmienia nawet to, że ich działanie jest dozwolone prawem. Moralność opiera się na innych kryteriach niż porządek prawny. Z prawnego punktu widzenia zabicie zwierzęcia przez myśliwego, który działa z niskich pobudek, ale dysponuje wszelkimi niezbędnymi zezwoleniami nie stanowi problemu - motywacja takiej osoby nie odgrywa tu żadnej roli” [Daniłowicz 2020, 35-37].

\section{PIŚMIENNICTWO}

Daniłowicz, Witold. 2018. Prawo polowania. Warszawa: Wolters Kluwer Polska.

Daniłowicz, Witold. 2020. „Czy chrześcijanin może być myśliwym (I).” Brać Łowiecka 12:29-31.

Dynak, Władysław. 2012. Łowiectwo w kulturze polskiej: obszary i kształty obecności. Wrocław: Wydawnictwo Uniwersytetu Wrocławskiego.

${ }^{32}$ Fragment kazania biskupa Stanisława Napierały, wygłoszonego w trakcie X Pielgrzymki Myśliwych Okręgu Kaliskiego 11 listopada 2012 r.: „,...] w dziejach ludzkości myślistwo plasuje się razem z rolnictwem na początku pełnienia danego przez Boga ludziom polecenia: Czyńcie sobie ziemię poddaną. Rolnicy posłuszni temu poleceniu uprawiali i uprawiają ziemię, by rodziła nam chleb i owoce, a myśliwi polowali i polują, aby zwierzęta i ptaki dostarczały nam mięso i odzienie. Nie wolno jednak działalności myśliwych sprowadzać tylko do polowania. Ich działalność jest bogata i różnorodna, nie tylko gospodarcza, ale i rekreacyjna, kulturowa. Myśliwi starają się szanować konkretne warunki, w jakich żyją zwierzęta i ptaki po to, by mądrze i odpowiedzialnie kierować rozwojem ich populacji, ochraniać ją przed grabieżą, dbać o odpowiednią jej liczebność i zdrowie. Myśliwi popularyzują też wiedzę o zwierzętach i ptakach, a umieją to pięknie czynić, bo znają świat przyrody. [...] Myśliwi są na ogół w większości ludźmi o żywym zmyśle wiary”. Zob. http://www.swietyjozef.kalisz.pl/HomilieBiskupa/95.html [dostęp: 16.01.2018]. 
Erdö, Péter. 2008. Storia delle fonti del diritto canonico. Venezia: Marcianum Press.

Gałkowski, Tomasz. 2017. „Zakaz przyjmowania publicznych urzędów przez duchownych." Łódzkie Studia Teologiczne 4 (26):111-22.

Ganowicz-Baczyk, Anita. 2016. „Człowiek, zwierzęta i moralność.” Zoophilologica. Polish Journal of Animal Studies 2:265-81.

Góralski, Woiciech. 2015. „Księga XV - De laicis w Dekrecie Burcharda z Wormacji.” Biuletyn Stowarzyszenia Kanonistów Polskich 28:59-78.

Kieling, Michał. 2012. „Dwanaście sposobów odpuszczenia grzechów? Praktyka pokutna wczesnośredniowiecznego Kościoła na podstawie Penitencjału Egberta." Teologia Praktyczna 13:83-95.

Kieling, Michał. 2017. „Zasady ogólne dotyczace praktyk pokutnych na podstawie Libri Poenitentiales." Vox Patrum 37 (67):225-40.

Kumor, Bolesław. 1973. Historia Kościoła. Cz. 2. Lublin: Katolicki Uniwersytet Lubelski.

Kwiatkowski, Dariusz. 2012. „Rzeczywistość grzechu i praktyki pokutne w Paenitentiale Vigilanum (Albeldense).” Liturgia Sacra 1 (18):113-26.

Łapiński, Jacek. 2002. „Etyczne podstawy prawnej ochrony zwierząt.” Studia z Prawa Wyznaniowego 4:141-62.

Micińska-Bojarek, Magdalena. 2014. Eowiectwo. Aspekt humanitarny i prawny. Poznań: Wydawnictwo Silva Rerum.

Mitek-Dziemba, Alina. 2018. „Myślistwo i religia. O religioznawczej ocenie praktyk łowieckich w perspektywie animal studies." Zoophilologica. Polish Journal of Animal Studies 4:71-87.

Morciniec, Piotr. 2005. „Status zwierząt w kontekście możliwości ksenotransplantacji.” Forum Teologiczne 6:75-93.

Nogaj, Tomasz. 2013. Dwie ambony. Łowiectwo i Kościót, czyli o słowach i o tym, co łaczy myślistwo $i$ Kościót katolicki $w$ Polsce $w$ historii, kulturze, języku i ceremoniach. Kraków: WAM. Księża Jezuici.

Pałęcki, Waldemar. 2012. „Nadużycia wobec Eucharystii w świetle średniowiecznych ksiąg pokutnych („Libri Poenitentiales”).” Roczniki Homiletyczno-Liturgiczne 3 (59): 127-55.

Paprocki, Henryk. 1976. „Hipolita Rzymskiego «Tradycja Apostolska»: wstęp, przekład, komentarz." Studia Theologica Varsaviensia 1 (14):145-69.

Piątek, Zdzisława. 2020. „O naturze myślistwa, przeszłość, teraźniejszość i przyszłość.” Filozofia i Nauka 2 (8):135-58.

Probucka, Dorota, red. 2020. Etyczne potępienie myślistwa. Kraków: Universitas.

Rancew-Sikora, Dorota. 2009. Sens polowania. Wspótczesne znaczenie tradycyjnych praktyk na przykładzie dyskursu towieckiego. Warszawa: Wydawnictwo Naukowe Scholar.

Singer, Peter. 2004. Wyzwolenie zwierzqt. Warszawa: Państwowy Instytut Wydawniczy.

Smykowski, Krzysztof. 2017. „Polowanie na zwierzęta w świetle podstawowych zasad teologii moralnej”. Studia Bydgoskie 11:225-36.

Story, Marek. 2020. „Sakrament chrztu w świetle średniowiecznych ksiag pokutnych.” Annales Canonici 2 (16):86-108. Doi: http://dx.doi.org/10.15633/acan.3832 
Subera, Ignacy. 1977. Historia źródet i nauki prawa kanonicznego. Warszawa: Akademia Teologii Katolickiej.

Szpetkowska, Beata. 2020. „Zamiennik pokut w ujęciu irlandzkich i brytyjskich ksiąg pokutnych.” Polonia Sacra 1 (59):113-34. Doi: http://dx.doi.org/10.15633/ps.3569

Urbaniak, Marcin. 2017. „Etyka i etykieta łowiecka jako narzędzia maskowania przemocy.” Edukacja Etyczna 13:3-29. Doi: http://dx.doi.10.24917/20838972.13.1

Witkowski, Wojciech. 2019. „Kościół wobec służby wojskowej i wojny w świetle wybranych kanonów ksiąg pokutnych od VI do XI wieku.” Littera Antiqua 14:57-71.

Zarzycki, Zdzisław. 2009. „Prawnowyznaniowe aspekty katolickiego duszpasterstwa leśników i myśliwych w Polsce." Studia z Prawa Wyznaniowego 12:71-89.

Zawadzki, Wojciech. 2010. „Bernharda Poschmanna nauka o pokucie wczesnośredniowiecznej." Studia Warmińskie 47:181-95.

\section{Polowania duchownych w świetle średniowiecznych ksiąg pokutnych}

\section{Streszczenie}

Księgi pokutne, które powstały w epoce późnej starożytności chrześcijańskiej i wczesnego średniowiecza są świadectwem kształtowania się praktyki pokutnej w Kościele. Miały one służyć pomocą spowiednikom, zwłaszcza w zakresie ujednolicenia nakładania pokuty.

Celem artykułu, jest udzielenie odpowiedzi, patrząc przez pryzmat ksiąg pokutnych, czy postawa Kościoła wobec łowiectwa była zawsze pozytywna, a zwłaszcza czy w taki sam sposób traktowano osoby świeckie, jak i duchowne? Analiza penitencjałów ukazuje, że w średniowieczu osoby duchowne zarówno diakonii, prezbiterzy, a według niektórych ksiąg pokutnych także i biskupi nie powinni brać udziału w polowaniach, zwłaszcza w celach rozrywkowych. Nie znajdujemy natomiast tekstów, które świadczyłyby o tym, że osoby świeckie nie mogą lub nie powinny brać udziału w polowaniach. Z przedmiotowych ksiąg wynika również, że pokuta za udział w polowaniach dla duchownych była surowa, jeśli porównamy ją do innych pokut, wymierzanych za poważne przewinienia. Obowiązujący Kodeks Prawa Kanonicznego nie przewiduje zakazu, aby duchowni nie mogli brać udziału w polowaniach, czy też otaczać troską myśliwych.

Słowa kluczowe: pokuta; księga pokutna; polowanie; Kodeks Prawa Kanonicznego z $1983 \mathrm{r}$.

\section{Hunting Practised by the Clergy in the Light of the Medieval Handbooks of Penance}

Summary

The handbooks of penance written during the Late Ancient Christianity and the Early Middle Ages are the evidence of the formation of the penitential practices in the 
Church. They were meant to help confessors, especially in regard to the unification of how penance was imposed.

This article aims to answer the question of whether, in the light of the handbooks of penance, the stance of the Church towards hunting was always positive, and whether the laity were treated in the same way as the clergy. The analysis of the handbooks of penance reveals that in the Middle Ages the members of the clergy, both deacons and priests, and, according to some sources, also bishops, were not supposed to take part in hunting, especially for entertainment. However, we do not find texts which suggest that laymen would not participate or were not allowed to participate in hunting. The said handbooks also indicate that penance for the clergy for participating in hunting activities was severe in comparison to the one imposed for serious wrongdoings.

Today, the Code of the Canon Law does not prohibit clergymen from hunting or showing care towards hunters.

Keywords: penance; handbook of penance; the 1983 Code of the Canon Law

Information about Author: REV. DR. MAREK STORY - Department of State and Law Studies, WSPiA University of Rzeszow; correspondence address: ul. Cegielniana 14, 35-310 Rzeszów, Poland; e-mail: mks80@wp.pl; https://orcid.org/0000-0003-3637-9684 